\title{
Brugada Syndrome: A Brief Review on Diagnostic Approach, Risk Stratification, and Management
}

\author{
Raymond Pranata \\ Department of Cardiology and Vascular Medicine, Siloam Hospitals Lippo Village - Faculty of Medicine, Universitas Pelita Harapan, Tangerang, Indonesia \\ ORCID: \\ Raymond Pranata: https://orcid.org/0000-0003-3998-6551
}

\section{Abstract}

Brugada syndrome is a congenital channelopathy in cardiac ion transmembrane causing an alteration in the electrical conduction of the heart. ST-elevation, as well as right bundle-branch block in anterior precordial electrocardiography (ECG), is pathognomonic in this syndrome. The patient might be asymptomatic or with a history of syncope and prone to develop ventricular tachyarrhythmia which may spontaneously recover or degenerates to ventricular fibrillation, cardiac arrest and even sudden death. Nevertheless, this can be prevented by implantable cardioverter defibrillator implantation. Therefore, it is of paramount importance that clinical suspicion and identification, interpretation of its characteristic ECG pattern and risk stratification to be properly done to diagnose and to manage Brugada syndrome. The author has also done a systematic review (included in the article) for several noninvasive ECG parameters for risk stratification with promising results. Epicardial ablation is an emerging therapy that may "cure" Brugada syndrome.

Keywords: Arrhythmia, Brugada syndrome, risk stratification, sudden cardiac death, syncope

\section{INTRODUCTION}

Brugada syndrome is a genetically determined channelopathy leading to syncope and ventricular tachyarrhythmia causing sudden death in those without evident structural heart disease. It was first mentioned in 1992. ${ }^{[1,2]}$ Brugada syndrome was commonly considered as an abnormality found commonly in young males (male: female ratio was 9:1) and Southeast Asian. It frequently manifests at the age of 40 years, causing sudden death frequently during sleep..$^{[3-5]}$ Suspicion should arouse when encountering a patient with a history of idiopathic ventricular fibrillation (VF) or polymorphic ventricular tachycardia (VT) that aborts spontaneously and family history of sudden death in young age with or without typical electrocardiography (ECG) findings. The incidence of Brugada syndrome in adults is approximately $0.05 \%-0.60 \%$ and the average age when the diagnosis is established is 41 years old. ${ }^{[6]}$

\section{Genetic Basis and Pathophysiology}

There are 18 genes that are associated with Brugada syndrome

Submission: 02-Aug-18 Accepted: 27-Sep-18

\begin{tabular}{|l|l|}
\hline \multicolumn{3}{|c|}{ Access this article online } \\
\hline Quick Response Code: & Website: \\
& www.ijcva.com \\
\hline
\end{tabular}

from BrS1 to BrS18. Basically, there are abnormalities in sodium, calcium, or potassium ion channels located at heart muscles..$^{[7,8]}$

\section{Sodium flow}

$\mathrm{BrS} 1$ gene was the first gene to be discovered which involves SCN5A at chromosome 3p21-23 encodes subunit $\alpha$ of sodium ion channel protein $(\mathrm{NaV} 1.5)$ which is responsible for depolarization (Phase 0 of action potential). Mutation results in loss-of-function of the sodium channel resulting in less sodium influx into the interior of the cell during depolarization. This mutation was also linked with other cardiac conduction defects (atrioventricular [AV] block, left bundle branch block, and left anterior fascicular block). ${ }^{[9,10]}$ $\mathrm{BrS} 2$ is responsible for mutations in glycerol-3-phosphate dehydrogenase 1-like protein reducing both the surface membrane expression and the inward sodium current. ${ }^{[1]}$ SCN1B plays a role in forming subunit $\beta 1$ of sodium ion

Address for correspondence: Dr. Raymond Pranata, Faculty of Medicine, Universitas Pelita Harapan, Tangerang, Indonesia. E-mail: raymond_pranata@hotmail.com

This is an open access journal, and articles are distributed under the terms of the Creative Commons Attribution-NonCommercial-ShareAlike 4.0 License, which allows others to remix, tweak, and build upon the work non-commercially, as long as appropriate credit is given and the new creations are licensed under the identical terms.

For reprints contact: reprints@medknow.com

How to cite this article: Pranata R. Brugada syndrome: A brief review on diagnostic approach, risk stratification, and management. Int J Cardiovasc Acad 2019;5:1-7. 
which modifies Nav1.5, thus increasing $I_{\mathrm{Na}}$ was the cause of BrS5. ${ }^{[12]}$ Meanwhile, BrS7 gene (SCN3B gene) forms subunit $\beta 3$ of sodium ion channels which alters Nav1.5 trafficking, thereby decreasing $I_{\mathrm{Na}}{ }^{[13]}$

\section{Calcium flow}

CACNA1C mutation results in BrS3 and CACNB2 cause BrS4. They are responsible for a defective unit of the L-type calcium channel. These mutation cause dysfunctions in subunit $\alpha$ and $\beta$ resulting in loss of function and reduced calcium influx culminating in shortening of the plateau phase of action potential. The $C A C N A 2 D 1$ gene was reported as responsible for $\mathrm{BrS}$. The $\alpha 2 / \delta$-subunit of voltage-dependent calcium channels regulates current density and activation/inactivation kinetics of the calcium channel. ${ }^{[7,8]}$

\section{Potassium flow}

KCNE3 gene plays a role in the formation of MiRP2 protein $\left(\beta\right.$-subunit that regulates the potassium channel $I_{\text {to }}$ ) and modulates some potassium currents in the heart. A recent study revealed that enhanced $I_{\text {to }}$ current gradient in the right ventricle was associated with KCND3 gain-of-function mutations (Kir4.3 protein). Another gene associated with $\mathrm{BrS}$ is $K C N J 8$, which was previously related to early repolarization syndrome and a marker of gain-of-function in the cardiac $\mathrm{K}$ (ATP) Kir6.1 channel. The KCNE5 gene, which is located in the $\mathrm{X}$ chromosome, encodes an auxiliary $\beta$-subunit for $\mathrm{K}$ channels causing gain-of-function effects on $I_{\text {to }}{ }^{[7,14]}$

The most prevalent is SCN5A mutation (20\% of cases), these dysfunctions resulted in an imbalance between outward and inward positive currents during repolarization causing heterogeneous loss of action potential dome during phase 2 . Increased dispersion of repolarization and refractoriness within epicardium and across the wall are associated with phase 2 re-entry mechanism resulting in ventricular arrhythmias. ${ }^{[15]}$ Most of the genetic variants found in Brugada syndrome remain of unknown significance because no comprehensive cellular studies have been performed. Genetic variants other than SCN5A may be responsible for only $2 \%-5 \%$ of diagnostic cases. Recently, there is a notion that Brugada syndrome may not be caused by a single mutation but rather by multiple susceptibility variants [Figure 1].

\section{Clinical Manifestation and Diagnosis}

VF or aborted sudden cardiac death (SCD), syncope, nocturnal agonal respiration, palpitations, and chest discomfort are associated with Brugada syndrome. These symptoms frequently occur during rest or sleep, fever, excess eating or binge drinking resulting in excess vagotonic condition nonetheless they rarely manifest during exercise. ${ }^{[8,16]}$ Symptoms occurring at young age signals an aggressive form of the disease. Overall 20\% experienced at least 1 syncope and only $10 \%-14 \%$ suffered cardiac arrest before 60 years old as was shown by international registries and meta-analysis. ${ }^{[6,17]}$ Drugs such as bupivacaine, cocaine, propafenone, methoxamine, $\beta$-blocker, potassium channel activator (pinacidil), a tricyclic

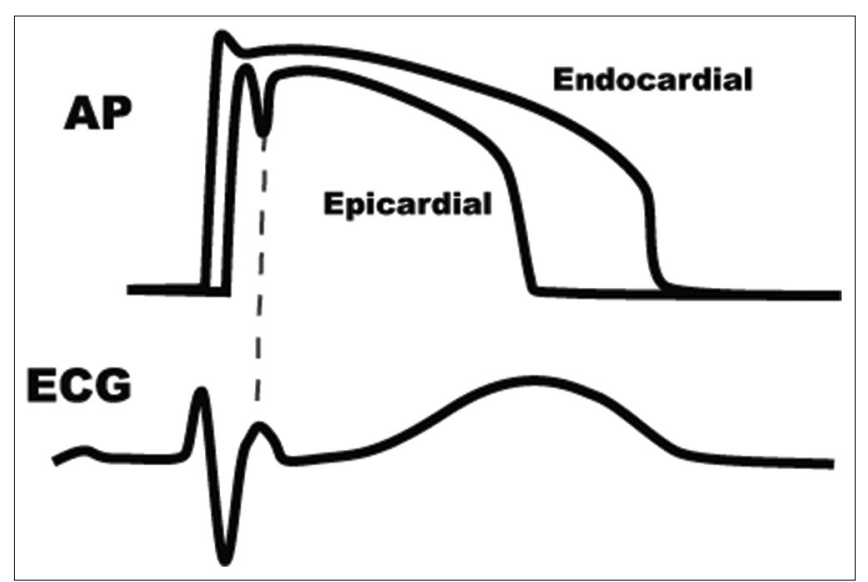

Figure 1: Difference in action potential in epicardial and endocardial myocyte in Brugada syndrome. Repolarization disorder hypothesis stated that the difference between action potential in the epicardial and endocardial myocyte resulted in the typical ST-elevation in Brugada syndrome

antidepressant, an opioid analgesic, lithium, and propofol exacerbates ECG pattern and potentially precipitating arrhythmia (visit Brugadadrugs.org). Diagnostic criteria of Brugada syndrome according to $2013 \mathrm{HRS} / \mathrm{EHRA} / \mathrm{APHRS}$ expert consensus statement is with ST-segment elevation with type I morphology $\geq 2 \mathrm{~mm}$ in $\geq 1$ lead among the right precordial leads V1, V2 positioned in the $2^{\text {nd }}, 3^{\text {rd }}$, or $4^{\text {th }}$ intercostal space occurring either spontaneously or after provocative drug test with intravenous administration of Class I antiarrhythmic drugs or in patients with type 2 or type 3 ST-segment elevation in $\geq 1$ lead among the right precordial leads V1, V2 positioned in the $2^{\text {nd }}, 3^{\text {rd }}$, or $4^{\text {th }}$ intercostal space when a provocative drug test with intravenous administration of Class I antiarrhythmic drugs induces a type I ECG morphology. ${ }^{[16]}$ According to international consensus conference on BrS ST-segment elevation of $\geq 2 \mathrm{~mm}$ in at least two of three precordial leads (V1-V3) with coved morphology associated with complete or incomplete right bundle-branch block was the ECG criteria to fulfill. Other ECG abnormalities that might be found are AV block and atrial fibrillation $\left(10 \%-25 \%\right.$ of patients). ${ }^{[8,18-21]}$ These atrial arrhythmias in Brugada syndrome were associated with genetic variants impairing the sodium channel function along with structural remodeling that promote AF by prolonging refractoriness and slowing conduction velocity which may be heterogeneous and facilitates the development of unidirectional block and re-entry, giving rise to atrial fibrillation, atrial flutter, and AV-nodal re-entry tachycardia. ${ }^{[22]}$

There are three typical ECG patterns in patients with Brugada syndrome. In type 1 there is a Coved ST-segment elevation $\geq 2 \mathrm{~mm}$ followed by $\mathrm{T}$ inversion in $>1$ precordial leads (V1-V3). ST-T segment saddleback configuration followed by positive or biphasic $\mathrm{T}$ wave is seen in type 2 ECG. Meanwhile, type 3 may show coved or saddleback with ST-segment elevation $<1 \mathrm{~mm}$ [Figure 2]. Typical ST segment changes might be found in patients with concealed form or type 2 or 3 ECG during provocation or fever. Therefore, in 


\begin{tabular}{|c|c|}
\hline & Points \\
\hline \multicolumn{2}{|l|}{ ECG (12-Lead/Ambulatory) } \\
\hline $\begin{array}{l}\text { Spontaneous type } 1 \text { Brugada ECG pattern at nominal or } \\
\text { high leads }\end{array}$ & 3.5 \\
\hline $\begin{array}{l}\text { Fever-induced type } 1 \text { Brugada ECG pattern at nominal } \\
\text { or high leads }\end{array}$ & 3 \\
\hline $\begin{array}{l}\text { Type } 2 \text { or } 3 \text { Brugada ECG pattern that converts with } \\
\text { provocative drug challenge }\end{array}$ & 2 \\
\hline \multicolumn{2}{|c|}{$\begin{array}{l}\text { Only award points once for highest score within this category. One item } \\
\text { from this category must apply. }\end{array}$} \\
\hline \multicolumn{2}{|c|}{ Clinical History* } \\
\hline $\begin{array}{l}\text { Unexplained cardiac arrest or documented VF/ } \\
\text { polymorphic VT }\end{array}$ & 3 \\
\hline Nocturnal agonal respirations & 2 \\
\hline Suspected arrhythmic syncope & 2 \\
\hline Syncope of unclear mechanism/unclear etiology & 1 \\
\hline $\begin{array}{l}\text { Atrial flutter/fibrillation in patients }<30 \text { years without } \\
\text { alternative etiology }\end{array}$ & 0.5 \\
\hline \multicolumn{2}{|l|}{ Family History* } \\
\hline First- or second-degree relative with definite $\mathrm{BrS}$ & 2 \\
\hline $\begin{array}{l}\text { Suspicious SCD (fever, nocturnal, Brugada aggravating } \\
\text { drugs) in a first- or second-degree relative }\end{array}$ & 1 \\
\hline $\begin{array}{l}\text { Unexplained } \mathrm{SCD}<45 \text { years in first- or second-degree } \\
\text { relative with negative autopsy }\end{array}$ & 0.5 \\
\hline \multicolumn{2}{|l|}{ Genetic test result } \\
\hline Probable pathogenic mutation in BrS susceptibility gene & 0.5 \\
\hline \multicolumn{2}{|c|}{$\begin{array}{l}\text { Score (requires at least } 1 \text { ECG finding). }>3.5 \text { points: Probable/definite } \\
\text { BrS. } 2-3 \text { points: Possible } \mathrm{BrS}<2 \text { points: Non-diagnostic }\end{array}$} \\
\hline $\begin{array}{l}\text { *Only award points once for highest score within this cates } \\
\text { BrS=Brugada syndrome; } \mathrm{SCD}=\text { sudden cardiac death; } \mathrm{VF}= \\
\text { fibrillation; } \mathrm{VT}=\text { ventricular tachycardia. Reproduced from } \\
\text { et al. }{ }^{[23]}\end{array}$ & $\begin{array}{l}\text { ular } \\
\text { evitch }\end{array}$ \\
\hline
\end{tabular}

patients with type 2 or 3 ECG findings, provocation with sodium channels inhibitor. ${ }^{[15]}$ [Figure 2]. There is also new diagnostic criteria of Brugada syndrome (Shanghai score) which was proposed in the consensus statement in 2016 [Table 1]. ${ }^{[23]}$ It is important to note in this new consensus, that asymptomatic patients with drug-induced type 1 ECG are considered to be at low risk and need some clinical manifestations to be diagnosed with Brugada syndrome. ${ }^{[23]}$

\section{Risk Stratification}

Almost all studies are in agreement that patient with type 1 baseline ECG and an episode of syncope have a high risk of cardiac arrhythmia in follow-up. The presence of QRS fragmentation and effective refractory period $<200 \mathrm{~ms}$ were also proposed. ${ }^{[24-26]}$ Risk of lethal or near-lethal arrhythmia episode in previously asymptomatic patient is $8 \%$, event rate at $33 \pm 39$ months follow-up was reported by Brugada et al.; $6 \%$ event rate in $34 \pm 44$ months by Priori et al.; $1 \%$ event rate was found at $40 \pm 50$ months and $30 \pm 21$ months follow-up by Eckardt et al. and Giustetto et al. ${ }^{[25,27-29]}$ Even though large registries are in agreement that electrophysiological study (EPS) inducibility was most frequently encountered

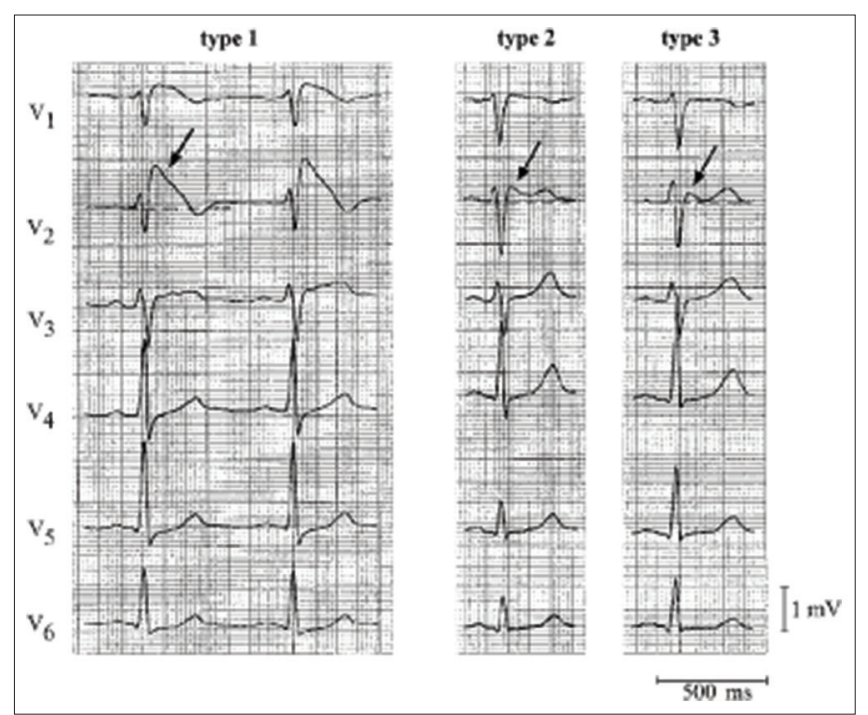

Figure 2: Electrocardiographic characteristics of Brugada pattern in precordial leads. electrocardiography in Brugada Syndrome. Type 1: Coved ST-elevation $\geq 2 \mathrm{~mm}$ followed by $\mathrm{T}$ wave deflection. Type 2: Gradually decreasing ST-elevation with saddleback pattern with positive or biphasic T wave and Type 3: coved or saddleback with $\geq 1 \mathrm{~mm}$ ST-elevation. ${ }^{[32]}$ From: Wilde AA, Antzelevitch C, Borggrefe M et al.; Study Group on the Molecular basis of arrhythmias of the European Society of Cardiology. Proposed diagnostic criteria for the Brugada syndrome. Eur Heart J 2002;23:1648-54

in those who experienced syncope or aborted sudden death, there is no consensus regarding the role of EPS. A study by Siera et al. showed 25 ventricular arrhythmia events, which consists of $16(21.9 \%)$ patients in the group that was successfully induced by EPS and $9(2.7 \%)$ patients that are not inducible. The aforementioned arrhythmia resulted in 24 appropriate implantable cardioverter defibrillator (ICD) shocks and 1 resuscitation because of cardiac arrest in those without ICD. The hazard ratio for an arrhythmic event in the future is $8.1(P<0.01)$ for those with inducible ventricular arrhythmia during the EPS study. ${ }^{[30]}$ EPS is controversial because the protocols are different between studies, for example; only from $\mathrm{RV}$ apex by Brugada group, but other groups from both apex and RVOT, up to double or triple extra stimuli, and minimal coupling interval to $200 \mathrm{~ms}$ or to $180 \mathrm{~ms}$, etc.). Recently, VF induction up to two extra stimuli is reported to be useful in the risk stratification of patients with Brugada syndrome. ${ }^{[27,31]}$

A study showed a Kaplan-Meier curve of $96.8 \%-99 \%$ event-free survival at $1,5,10$, and 15 years in noninducible ventricular arrhythmia during EPS. It is concluded that in a patient with asymptomatic clinical presentation alone in those with noninducible groups has $99.2 \%$ event-free survival at $1,5,10$, and 15 years. ${ }^{[30,32]}$ Hence, EPS is an excellent predictor in both asymptomatic or those presenting with syncope $^{[2]}$ [Figure 3].

There were also studies that enlist additional tools for the risk stratification mainly Tpeak-end interval (TpTe), Tp-e dispersion, and TpTe/QT ratio [Table 2]..$^{[33-41]}$ There were five 


\begin{tabular}{|c|c|c|c|c|c|c|}
\hline Authors & Year & Study design & Samples & Subjects & Outcome of interest & Results \\
\hline $\begin{array}{l}\text { Morita } \mathrm{H} \\
\text { et al. }\end{array}$ & 2018 & $\begin{array}{l}\text { Case-control } \\
\text { study }\end{array}$ & 62 & $\begin{array}{l}\text { Brugada-type } \\
\text { ECG }\end{array}$ & Initial VF & $\begin{array}{l}\text { OR of difference Tpe interval (V1) } \geq+10 \mathrm{~ms}: 11.0, \mathrm{CI} \text { : } \\
2.6-46.1, P=0.001\end{array}$ \\
\hline $\begin{array}{l}\text { Morita } \mathrm{H} \\
\text { et al. }\end{array}$ & 2018 & $\begin{array}{l}\text { Retrospective } \\
\text { Cohort }\end{array}$ & 471 & $\mathrm{BrS}$ & VF & $\begin{array}{l}\mathrm{TpTe}(\mathrm{ms}) \mathrm{V} 2 \geq 95 \text { was associated with HR } \\
3.031 .26-9.010 .0143\end{array}$ \\
\hline Zumhagen & 2016 & $\begin{array}{l}\text { Case-control } \\
\text { study }\end{array}$ & 78 & $\mathrm{BrS}$ & $\mathrm{VT} / \mathrm{VF} /$ aborted SCD & $\begin{array}{l}\mathrm{TpTe} \geq 77 \mathrm{~ms}, 63.6 \% \text { and } 74.1 \% \text {; AUC } 0.675, \mathrm{TpTe} / \mathrm{QT} \\
\text { ratio } \geq 0.205,72.7 \% \text { and } 68.5 \% \text {; AUC } 0.673\end{array}$ \\
\hline Maury P & 2015 & $\begin{array}{l}\text { Case-control } \\
\text { study }\end{array}$ & 325 & $\mathrm{BrS}$ & $\begin{array}{l}\text { Sudden death/ } \\
\text { appropriate ICD shocks }\end{array}$ & $\begin{array}{l}\text { Maximum Tpe }>100 \mathrm{~ms} \text { OR of } 9.61(95 \% \text { CI } 3.13-9.41) \\
(P<0.0001) \text {. Sensitivity } 84 \% \text { and Specificity } 68 \% \text {, PPV } \\
19 \% \text {, NPV } 98 \%\end{array}$ \\
\hline Mugnai & 2017 & Cohort & 448 & $\mathrm{BrS}$ & $\begin{array}{l}\mathrm{VT} / \mathrm{VF} / \mathrm{SCD} / \\
\text { appropriate ICD shocks }\end{array}$ & $\begin{array}{l}\text { No significant difference was observed in } \mathrm{TpTe}, \mathrm{TpTe} / \\
\mathrm{QT} \text {, maximum TpTe, and TpTe dispersion }\end{array}$ \\
\hline Kawazoe & 2016 & $\begin{array}{l}\text { Case-control } \\
\text { study }\end{array}$ & 143 & $\mathrm{BrS}$ & $\mathrm{VF}$ & $\begin{array}{l}\text { Tpe dispersion OR } 1.069 \text { (1.03-1.10), P: } 0.001 \\
\text { independent predictor }\end{array}$ \\
\hline \multirow[t]{2}{*}{ Letsas } & 2010 & $\begin{array}{l}\text { Case-control } \\
\text { study }\end{array}$ & 23 & $\mathrm{BrS}$ & VT/VF inducibility & $\begin{array}{l}\text { TpTe V2 }(88.82+15.70 \text { vs. } 78.33+4.08 \mathrm{~ms}, P=0.02) \text { and } \\
\text { V6 }(76.33+10.08 \text { vs. } 66.66+5.16 \mathrm{~ms}, P=0.04)\end{array}$ \\
\hline & & & & & & $\begin{array}{l}\text { Greater Tpeak-Tend/QT ratio in lead V6 }(0.214+0.028 \\
\text { vs. } 0.180+0.014, P=0.009)\end{array}$ \\
\hline \multirow[t]{4}{*}{ Hevia JC } & 2006 & Cohort & 29 & $\mathrm{BrS}$ & $\mathrm{VT} / \mathrm{VF}$ & $\mathrm{QTc}>460 \mathrm{~ms}$ in $\mathrm{V} 2$ \\
\hline & & & & & & $\begin{array}{l}\mathrm{TpTe} \text { and } \mathrm{Tp} \text {-e dispersion were significantly prolonged in } \\
\text { patients with recurrences versus patients without events }\end{array}$ \\
\hline & & & & & & $\begin{array}{l}\text { TpTe cut-off point }>100 \mathrm{~ms} \text {; Sensitivity } 77.8 \% \text { and } \\
\text { specificity } 70 \% \text {; AUC } 0.7861\end{array}$ \\
\hline & & & & & & $\begin{array}{l}\text { Tp-e dispersion Cut-off point }>20 \mathrm{~ms} \text {; Sensitivity } 66.7 \% \\
\text { and specificity } 90 \% \text {; AUC } 0.7722\end{array}$ \\
\hline
\end{tabular}

TpTe: Tpeak-Tend interval, SCD: Sudden cardiac death, ICD: Implantable cardioverter defibrillator, VF: Ventricular fibrillation, VT: Ventricular tachycardia, ECG: Electrocardiography, OR: Odds ratio, CI: Confidence interval, AUC: Area under the curve, PPE: Positive predictive value, NPE: Negative predictive value, BrS: Brugada Syndrome, HR: Hazard ratio

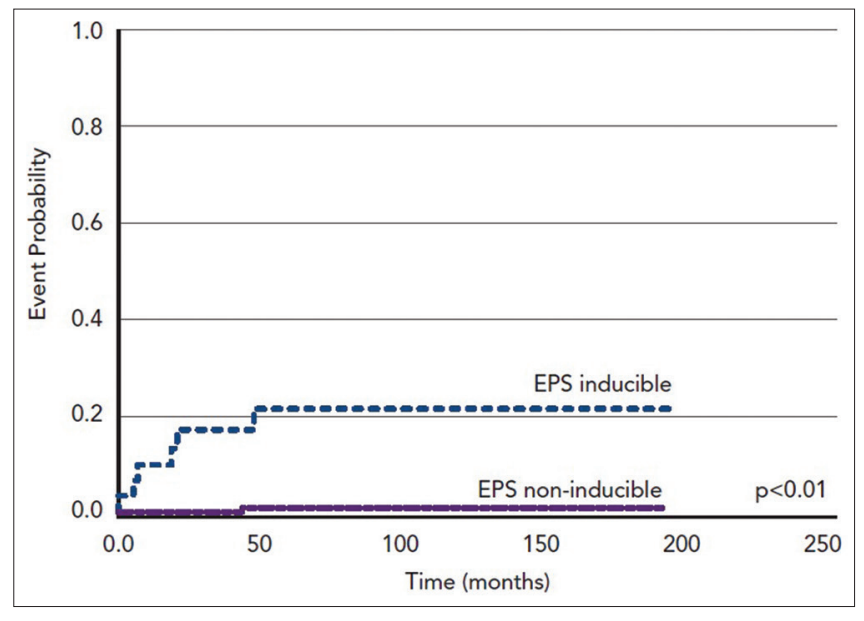

Figure 3: Kaplan-Meier curve showing high event-free survival of EPS noninducible patients. Patients had $96.8 \%-99 \%$ event free survival at $1,5,10$ and 15 years in non-inducible ventricular arrhythmia during electrophysiological study ${ }^{[32]}$

studies that showed TpTe was reliable in predicting VT/VF in patient with Brugada syndrome, the cut-off points varied between precordial leads from $\geq 80 \mathrm{~ms}$ to $\geq 100 \mathrm{~ms}$ in which two studies reported a sensitivity $77.8 \%-84 \%$ and specificity $68 \%-70 \%$; positive predictive value $19 \%$, negative predictive value $98 \%$, odds ratio (OR) 9.61 (95\% confidence interval 3.13-9.41) $(P<0.0001)$, area under the curve (AUC) 0.7861 with $\geq 100 \mathrm{~ms}$. Morita et al. indicated TpTe progression of $>10$ ms on repeat ECG was associated with OR $11.6(P=0.001)$. Zumhagen et al. showed that $\mathrm{TpTe} / \mathrm{QT}$ ratio is reliable in predicting VT/VF in which a ratio of $\geq 0.205$ has sensitivity $72.7 \%$ and specificity $68.5 \%$; AUC 0.673 . Two studies reported that Tp-e dispersion was associated with VT/VF one of which reported Cut-off point $>20 \mathrm{~ms}$; sensitivity $66.7 \%$ and Specificity $90 \%$; AUC 0.7722 . Only Mugnai et al. revealed the nonsignificant relation of the aforementioned parameters and VT/VF. Letsas et al. indicated that TpTe and greater TpTe/QT ratio in lead V6 are related to VT/VF inducibility, but the latter was not related to the arrhythmic outcome. Spontaneous type 1 ECG, syncope, early repolarization pattern, age (the elderly is at lower risk), and SCN5A mutation (pore lesion) were also associated with higher risk. ${ }^{[42-44]}$

\section{Management}

Drugs that may induce or aggravate ST-segment elevation in the right precordial leads should be avoided (visit Brugadadrugs.org). Excessive alcohol intake should be avoided, and immediate treatment of fever with antipyretic drugs are Class I recommendation [Table 3]. ICD implantation is the only effective modality in Brugada syndrome. Brugada syndrome patients who are survivors of a cardiac arrest and/or have documented spontaneous sustained VT with or without syncope had a Class I recommendation for ICD implantation. Implantation of ICD is recommended (Class IIa) in a patient with syncope (if syncope is suspected as arrhythmic origin) 
and spontaneously abnormal ECG (without provocation) because those patients have six times increased risk of cardiac arrest compared to those showing type I ECG after provocation. ${ }^{[2,6]}$ The risk is very low when the diagnosis was

\section{Table 3: Recommendation on therapy and intervention in patient with Brugada Syndrome}

\begin{tabular}{|c|c|}
\hline $\begin{array}{l}\text { Class of } \\
\text { Recommendation }\end{array}$ & Intervention \\
\hline Class I & $\begin{array}{l}\text { The following lifestyle changes are recommended in all patients with diagnosis of BrS } \\
\text { Avoidance of drugs that may induce or aggravate ST-segment elevation in right precordial leads } \\
\text { Avoidance of excessive alcohol intake } \\
\text { Immediate treatment of fever with antipyretic drugs } \\
\text { ICD implantation is recommended in patients with a diagnosis of BrS who } \\
\text { Are survivors of a cardiac arrest and/or } \\
\text { Have documented spontaneous sustained VT with or without syncope }\end{array}$ \\
\hline Class IIa & $\begin{array}{l}\text { ICD implantation can be useful in patients with a spontaneous diagnostic type I ECG who have a history of syncope judged to be } \\
\text { likely } \\
\text { caused by ventricular arrhythmia } \\
\text { Quinidine can be useful in patients with a diagnosis of BrS and history of arrhythmic storms defined as more than two episodes of VT/ } \\
\text { VF in } 24 \mathrm{~h} \\
\text { Quinidine can be useful in patients with a diagnosis of BrS } \\
\text { Who qualify for an ICD but present a contraindication to the ICD or refuse it and/or } \\
\text { Have a history of documented supraventricular arrhythmias that require treatment } \\
\text { Isoproterenol infusion can be useful in suppressing arrhythmic storms in BrS patients }\end{array}$ \\
\hline Class IIb & $\begin{array}{l}\text { ICD implantation may be considered in patients with a diagnosis of BrS who develop VF during programmed electrical stimulation } \\
\text { (inducible patients) } \\
\text { Quinidine may be considered in asymptomatic patients with a diagnosis of BrS with a spontaneous type } 1 \mathrm{ECG} \\
\text { Catheter ablation may be considered in patients with a diagnosis of } \mathrm{BrS} \text { and history of arrhythmic storms or repeated appropriate ICD } \\
\text { shocks }\end{array}$ \\
\hline Class III & $\begin{array}{l}\text { ICD implantation is not indicated in asymptomatic BrS patients with a drug-induced type } 1 \text { ECG and on the basis of a family history } \\
\text { of SCD alone }\end{array}$ \\
\hline
\end{tabular}

Expert Consensus Recommendations on BrS Therapeutic Interventions. Priori et al. SCD: Sudden cardiac death, ICD: Implantable cardioverter defibrillator, VF: Ventricular fibrillation, VT: Ventricular tachycardia, ECG: Electrocardiography, BrS: Brugada Syndrome

\section{Type 1 Brugada pattern}

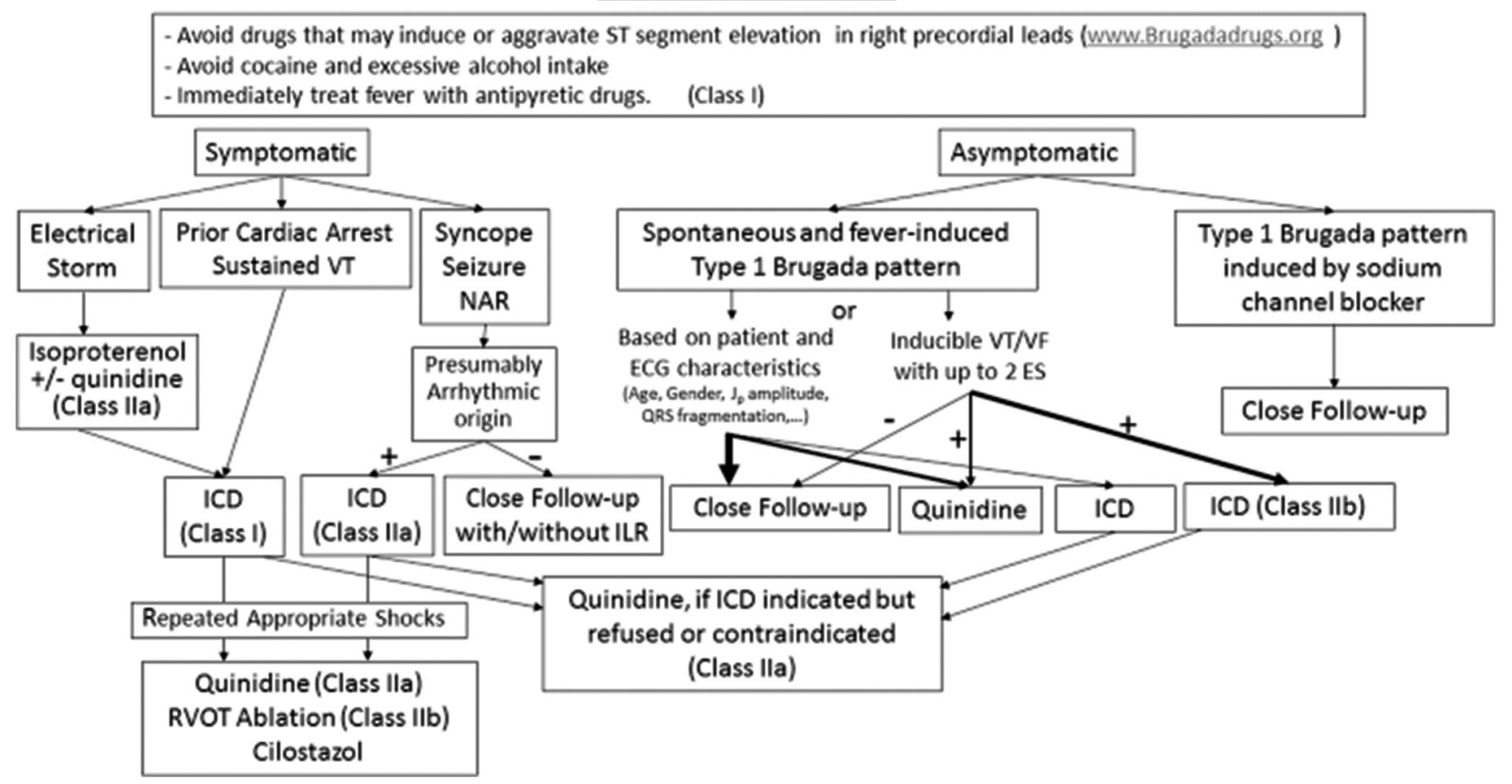

Figure 4: Indications for therapy of patients with Brugada syndrome. The figure above provide flowchart regarding the indications for therapy of patients with Brugada syndrome ${ }^{[23]}$ 
made after provocation test with sodium ion channel blockers or by identification of pathogenic mutation only. Follow-up may be needed to observe changes in ECG morphology, from previously requiring provocation to display typical ECG into spontaneously abnormal ECG. ${ }^{[8]}$ Management in a patient with spontaneously abnormal type 1 ECG without a history of syncope is controversial, the risk of life-threatening events in this group is two-fold higher in those without spontaneously ST-segment elevation. ${ }^{[6,17]}$ EPS may be beneficial in this group. However, its role is still controversial, and ICD implantation (Class IIb) may be considered those who develop VF during programmed electrical stimulation (inducible patients) [Figure 4]. QRS fragmentation in these patients was also associated with a worse prognosis. ${ }^{[24]}$ Quinidine, which is the best antiarrhythmic medication available for Brugada syndrome is only used as an adjunct therapy for high-risk patients and to reduce the number of ICD shocks in those with recurrent events. ${ }^{[8]}$ Quinidine may be considered in asymptomatic patients with a diagnosis of Brugada syndrome with a spontaneous type I ECG (Class IIb). Catheter ablation can be considered Brugada syndrome patients with a history of arrhythmic storms or repeated appropriate ICD shocks (Class IIb). Finally, ICD implantation is not indicated in asymptomatic Brugada syndrome patients with a drug-induced type I ECG and on the basis of a family history of SCD alone (Class III).

Epicardial ablation is an emerging treatment in the field of Brugada syndrome. Nademanee et al. showed that 9 patients with Brugada syndrome experiencing 2-6 incidence of ventricular arrhythmia per month was arrhythmia free in a follow-up of 2 years after ablation. ${ }^{[4]}$ Brugada et al. reported that ablation of the substrate identified in the presence of flecainide could eliminate the Brugada syndrome phenotype. ${ }^{[45]}$ Pappone et al. in a study of 50 consecutive patients that underwent ablation showed that ECG pattern normalized in all symptomatic and asymptomatic patients. ${ }^{[46]}$ Follow-up of 3 to 20 months showed that the patients showed no Brugada syndrome phenotype and was not VT/VF inducible seemingly "cured" the Brugada syndrome. Pappone stated that ablation could be useful in those that do not meet the recommendation or refuse ICD implantation. A multicenter randomized trial, ablation in Brugada syndrome for the prevention of VF episodes Study was underway. These findings may usher a new era in treating Brugada syndrome, and the possibility of epicardial ablation being a first-line treatment in the future cannot be overruled.

\section{Financial support and sponsorship}

Nil.

\section{Conflicts of interest}

There are no conflicts of interest.

\section{References}

1. Brugada P, Brugada J. Right bundle branch block, persistent ST segment elevation and sudden cardiac death: A distinct clinical and electrocardiographic syndrome. A multicenter report. J Am Coll Cardiol 1992;20:1391-6.

2. Antzelevitch C, Brugada P, Borggrefe M, Brugada J, Brugada R, Corrado D, et al. Brugada syndrome: Report of the second consensus conference: Endorsed by the Heart Rhythm Society and the European Heart Rhythm Association. Circulation 2005;111:659-70.

3. Matsuo K, Akahoshi M, Nakashima E, Suyama A, Seto S, Hayano M, et al. The prevalence, incidence and prognostic value of the Brugada-type electrocardiogram: A population-based study of four decades. J Am Coll Cardiol 2001;38:765-70.

4. Shimizu W. Clinical impact of genetic studies in lethal inherited cardiac arrhythmias. Circ J 2008;72:1926-36.

5. Ruan Y, Liu N, Priori SG. Sodium channel mutations and arrhythmias. Nat Rev Cardiol 2009;6:337-48.

6. Priori SG, Napolitano C, Gasparini M, Pappone C, Della Bella P, Giordano U, et al. Natural history of Brugada syndrome: Insights for risk stratification and management. Circulation 2002;105:1342-7.

7. Brugada $P$, Brugada $R$, Campuzano $O$, Sarquella-Brugada G, Brugada P, Brugada V, et al. Brugada syndrome 1992-2012: Twenty years of scientific progress. In: Zipes DP, Jalife J, editors. Cardiac Electrophysiology: From Cell to Bedside. $6^{\text {th }}$ ed. Philadelphia: Elsevier; 2014. p. 925-31.

8. Priori SG, Napolitano C. Genetics of channelopathies and clinical implications. In: Fuster V, Walsh AR, Harrington RA, editors. Hurst's the Heart. $13^{\text {th }}$ ed. New York: McGraw-Hill; 2011. p. 903-6.

9. Probst V, Allouis M, Sacher F, Pattier S, Babuty D, Mabo P, et al. Progressive cardiac conduction defect is the prevailing phenotype in carriers of a Brugada syndrome SCN5A mutation. J Cardiovasc Electrophysiol 2006;17:270-5.

10. Bai R, Napolitano C, Bloise R, Monteforte N, Priori SG. Yield of genetic screening in inherited cardiac channelopathies: How to prioritize access to genetic testing. Circ Arrhythm Electrophysiol 2009;2:6-15.

11. London B, Michalec M, Mehdi H, Zhu X, Kerchner L, Sanyal S, et al. Mutation in glycerol-3-phosphate dehydrogenase 1 like gene (GPD1-L) decreases cardiac na+current and causes inherited arrhythmias. Circulation 2007;116:2260-8.

12. Watanabe H, Darbar D, Kaiser DW, Jiramongkolchai K, Chopra S, Donahue BS, et al. Mutations in sodium channel $\beta 1$ - And $\beta 2$-subunits associated with atrial fibrillation. Circ Arrhythm Electrophysiol 2009;2:268-75.

13. Hu D, Barajas-Martinez H, Burashnikov E, Springer M, Wu Y, Varro A, et al. A mutation in the beta 3 subunit of the cardiac sodium channel associated with Brugada ECG phenotype. Circ Cardiovasc Genet 2009;2:270-8.

14. Delpón E, Cordeiro JM, Núñez L, Thomsen PE, Guerchicoff A, Pollevick GD, et al. Functional effects of KCNE3 mutation and its role in the development of Brugada syndrome. Circ Arrhythm Electrophysiol 2008;1:209-18.

15. Cygankiewicz I, Zareba W. Channelopathies. In: Steinberg JS, Mittal S, editors. Electrophysiology: The Basics. $13^{\text {th }}$ ed. Philadelphia: Lippincott Williams and Wilkins; 2010. p. 903-6.

16. Priori SG, Wilde AA, Horie M, Cho Y, Behr ER, Berul C, et al. HRS/ EHRA/APHRS expert consensus statement on the diagnosis and management of patients with inherited primary Arrhythmia syndromes: Document endorsed by HRS, EHRA, and APHRS in may 2013 and by ACCF, AHA, PACES, and AEPC in June 2013. Heart Rhythm 2013;10:1932-63.

17. Paul M, Gerss J, Schulze-Bahr E, Wichter T, Vahlhaus C, Wilde AA, et al. Role of programmed ventricular stimulation in patients with Brugada syndrome: A meta-analysis of worldwide published data. Eur Heart J 2007;28:2126-33.

18. Fowler SJ, Priori SG. Clinical spectrum of patients with a Brugada ECG. Curr Opin Cardiol 2009;24:74-81.

19. Pappone C, Radinovic A, Manguso F, Vicedomini G, Sala S, Sacco FM, et al. New-onset atrial fibrillation as first clinical manifestation of latent Brugada syndrome: Prevalence and clinical significance. Eur Heart J 2009;30:2985-92.

20. Morita H, Kusano-Fukushima K, Nagase S, Fujimoto Y, Hisamatsu K, Fujio $\mathrm{H}$, et al. Atrial fibrillation and atrial vulnerability in patients with Brugada syndrome. J Am Coll Cardiol 2002;40:1437-44. 
21. Wilde AA, Antzelevitch C, Borggrefe M, Brugada J, Brugada R, Brugada $\mathrm{P}$, et al. Proposed diagnostic criteria for the Brugada syndrome. Eur Heart J 2002;23:1648-54.

22. Hasdemir C. Atrial arrhythmias in inherited arrhythmogenic disorders. J Arrhythm 2016;32:366-72.

23. Antzelevitch C, Yan G, Ackerman MJ, Borggrefe M, Corrado D, Guo J, et al. J-Wave syndromes expert consensus conference report: Emerging concepts and gaps in knowledge. EP Europace 2017;19:665-94.

24. Morita H, Kusano KF, Miura D, Nagase S, Nakamura K, Morita ST, et al. Fragmented QRS as a marker of conduction abnormality and a predictor of prognosis of Brugada syndrome. Circulation 2008;118:1697-704.

25. Priori SG, Gasparini M, Napolitano C, Della Bella P, Ottonelli AG, Sassone B, et al. Risk stratification in Brugada syndrome: Results of the PRELUDE (PRogrammed ELectrical stimUlation preDictive valuE) registry. J Am Coll Cardiol 2012;59:37-45.

26. Makimoto H, Kamakura S, Aihara N, Noda T, Nakajima I, Yokoyama T, et al. Clinical impact of the number of extrastimuli in programmed electrical stimulation in patients with Brugada type 1 electrocardiogram. Heart Rhythm 2012;9:242-8.

27. Brugada J, Brugada R, Brugada P. Determinants of sudden cardiac death in individuals with the electrocardiographic pattern of Brugada syndrome and no previous cardiac arrest. Circulation 2003;108:3092-6.

28. Eckardt L, Probst V, Smits JP, Bahr ES, Wolpert C, Schimpf R, et al. Long-term prognosis of individuals with right precordial ST-segment-elevation Brugada syndrome. Circulation 2005;111:257-63.

29. Giustetto C, Drago S, Demarchi PG, Dalmasso P, Bianchi F, Masi AS, et al. Risk stratification of the patients with Brugada type electrocardiogram: A community-based prospective study. Europace 2009;11:507-13.

30. Yuniadi Y. Kontroversi peran studi elektrofisiologi pada sindrom Brugada. J Kardiol Indones 2015;36:183-5.

31. Sroubek J, Probst V, Mazzanti A, Delise P, Hevia JC, Ohkubo K, et al. Programmed ventricular stimulation for risk stratification in the Brugada syndrome: A Pooled analysis. Circulation 2016;133:622-30.

32. Sieira J, Conte G, Ciconte G, de Asmundis C, Chierchia GB, Baltogiannis G, et al. Prognostic value of programmed electrical stimulation in Brugada syndrome: 20 years experience. Circ Arrhythm Electrophysiol 2015;8:777-84.

33. Morita H, Miyamoto M, Watanabe A, Tsukuda S, Morimoto Y, Kawada S, et al. Progression of electrocardiographic abnormalities associated with initial ventricular fibrillation in asymptomatic patients with Brugada syndrome. Heart Rhythm 2018. pii: S1547-5271 (18) 30614-3.

34. Morita H, Watanabe A, Kawada S, Miyamoto M, Morimoto Y, Nakagawa K, et al. Identification of electrocardiographic risk markers for the initial and recurrent episodes of ventricular fibrillation in patients with Brugada syndrome. J Cardiovasc Electrophysiol 2018;29:107-14.
35. Zumhagen S, Zeidler EM, Stallmeyer B, Ernsting M, Eckardt L, Schulze-Bahr E, et al. Tpeak-tend interval and tpeak-tend/QT ratio in patients with Brugada syndrome. Europace 2016;18:1866-72.

36. Maury P, Sacher F, Gourraud JB, Pasquié JL, Raczka F, Bongard V, et al. Increased tpeak-tend interval is highly and independently related to arrhythmic events in Brugada syndrome. Heart Rhythm 2015;12:2469-76

37. Mugnai G, Hunuk B, Hernandez-Ojeda J, Stroker E, Velagic V, Ciconte $\mathrm{G}$, et al. Role of electrocardiographic tpeak-tend for the prediction of ventricular arrhythmic events in the Brugada syndrome. Am J Cardiol 2017;120:1332-7.

38. Kawazoe H, Nakano Y, Ochi H, Takagi M, Hayashi Y, Uchimura Y, et al. Risk stratification of ventricular fibrillation in Brugada syndrome using noninvasive scoring methods. Heart Rhythm 2016;13:1947-54

39. Letsas KP, Weber R, Astheimer K, Kalusche D, Arentz T. Tpeak-tend interval and tpeak-tend/QT ratio as markers of ventricular tachycardia inducibility in subjects with Brugada ECG phenotype. Europace 2010;12:271-4.

40. Castro Hevia J, Antzelevitch C, Tornés Bárzaga F, Dorantes Sánchez M, Dorticós Balea F, Zayas Molina R, et al. Tpeak-tend and tpeak-tend dispersion as risk factors for ventricular tachycardia/ventricular fibrillation in patients with the Brugada syndrome. J Am Coll Cardiol 2006;47:1828-34.

41. Nademanee K, Veerakul G, Chandanamattha P, Chaothawee L, Ariyachaipanich A, Jirasirirojanakorn K, et al. Prevention of ventricular fibrillation episodes in Brugada syndrome by catheter ablation over the anterior right ventricular outflow tract epicardium. Circulation 2011;123:1270-9.

42. Tokioka K, Kusano KF, Morita H, Miura D, Nishii N, Nagase S, et al. Electrocardiographic parameters and fatal arrhythmic events in patients with Brugada syndrome: Combination of depolarization and repolarization abnormalities. J Am Coll Cardiol 2014;63:2131-8.

43. Kamakura T, Wada M, Nakajima I, Ishibashi K, Miyamoto K, Okamura H, et al. Evaluation of the necessity for cardioverter-defibrillator implantation in elderly patients with Brugada syndrome. Circ Arrhythm Electrophysiol 2015;8:785-91

44. Yamagata K, Horie M, Aiba T, Ogawa S, Aizawa Y, Ohe T, et al. Genotype-phenotype correlation of SCN5A mutation for the clinical and electrocardiographic characteristics of Probands with Brugada syndrome: A Japanese multicenter registry. Circulation 2017;135:2255-70.

45. Brugada J, Pappone C, Berruezo A, Vicedomini G, Manguso F, Ciconte $\mathrm{G}$, et al. Brugada syndrome phenotype elimination by epicardial substrate ablation. Circ Arrhythm Electrophysiol 2015;8:1373-81.

46. Pappone C, Brugada J, Vicedomini G, Ciconte G, Giannelli L, Saviano $\mathrm{M}$, et al. Epicardial ablation in Brugada syndrome. Insights from a prospective registry study of 50 consecutive patients. EP Europace 2016;18 Suppl 1:i25. 